Article

\title{
Cytotoxic Psammaplysin Analogues from the Verongid Red Sea Sponge Aplysinella Species
}

\author{
Lamiaa A. Shaala $1,2,3, *$ (D) and Diaa T. A. Youssef $4,5, *$ (D) \\ 1 Natural Products Unit, King Fahd Medical Research Center, King Abdulaziz University, Jeddah 21589, \\ Saudi Arabia \\ 2 Department of Medical Laboratory Technology, Faculty of Applied Medical Sciences, King Abdulaziz \\ University, Jeddah 21589, Saudi Arabia \\ 3 Suez Canal University Hospital, Suez Canal University, Ismailia 41522, Egypt \\ 4 Department of Natural Products, Faculty of Pharmacy, King Abdulaziz University, Jeddah 21589, \\ Saudi Arabia \\ 5 Department of Pharmacognosy, Faculty of Pharmacy, Suez Canal University, Ismailia 41522, Egypt \\ * Correspondence: 1shalla@kau.edu.sa or lamiaelnady@yahoo.com (L.A.S.); dyoussef@kau.edu.sa or \\ diaa22@yahoo.com (D.T.A.Y.); Tel.: +966-548-751-044 (L.A.S); +966-548-535-344 (D.T.A.Y.)
}

Received: 6 November 2019; Accepted: 6 December 2019; Published: 8 December 2019

\begin{abstract}
As part of our ongoing interest to identify bioactive chemical entities from marine invertebrates, the Red Sea specimen of the Verongid sponge Aplysinella species was studied. Repeated chromatographic fractionation of the methanolic extract of the sponge and HPLC purification of the cytotoxic fractions led to the isolation and the identification of two new compounds, psammaplysin $\mathrm{Z}$ and 19-hydroxypsammaplysin $\mathrm{Z}$ (1 and 2), together with the previously reported psammaplysins A (3) and E (4). The structural determination of 1-4 was supported by interpretation of their NMR and high-resolution mass spectra. Psammaplysins A and E displayed cytotoxic activity against MBA-MB-231 and HeLa cell lines with $\mathrm{IC}_{50}$ values down to $0.29 \mu \mathrm{M}$. On the other hand, psammaplysin $\mathrm{Z}$ and 19-hydroxypsammaplysin $\mathrm{Z}$ were moderately cytotoxic, indicating the importance of the terminal amine and 2-(methylene)cyclopent-4-ene-1,3-dione moieties in $\mathbf{3}$ and $\mathbf{4}$ for potent cytotoxic activity.
\end{abstract}

Keywords: Order Verongiida; Red Sea sponges; Aplysinella species; bromotyrosine-derived metabolites; psammaplysin A; psammaplysin E; psammaplysin Z and 19-hydroxypsammaplysin Z; cytotoxicity; human cancer cell lines

\section{Introduction}

Marine invertebrates are considered as an excellent source of biologically active biomolecules. Marine sponges, phylum Porifera, represent an attractive subject for chemists and pharmacologists, who target marine-derived biomolecules. Members of the order Verongiida are characterized by production of brominated compounds that are biosynthesized from bromotyrosine [1]. Compounds possessing the rare dibrominated 1,6-dioxa-2-azaspiro[4.6]undeca-2,7,9-triene moiety (spirooxepinisoxazoline) are derived from bromotyrosine and are named psammaplysins [2-10], ceratinamides $[9,11]$ and ceratinadins [12]. Compounds with the spirooxepinisoxazoline moiety were reported mainly from members of the Verongiida [2-10,12] with only two representatives from the order Dictyoceratida [11,13]. Psammaplysins' backbone consists of two dibrominated subunits, 8,10-dibromo-4-hydroxy-9-methoxy-1,6-dioxa-2-azaspiro[4.6] undeca-2,7,9-triene-3-carboxylic acid (subunit A) and 3-(4-(2-aminoethyl)-2,6-dibromophenoxy)propan-1-amine subunit (subunit B, moloka'iamine) [14], connected together through an amidic linkage between the carboxylic moiety 
(C-9) of the substituted spirooxepinisoxazoline unit and the terminal amino group at C-10 of the moloka'iamine (Figure 1) to give the first reported compound of this class, psammaplysin $A$, (N-(3-(4-(2-aminoethyl)-2,6-dibromophenoxy)propyl)-8,10-dibromo-4-hydroxy-9-methoxy-1,6-dioxa-2azaspiro[4.6] undeca-2,7,9-triene-3-carboxamide) [2]. Interestingly, moloka'iamine (subunit B) and its substituted derivatives were reported from several Verongid sponges [9,13-15], but there is no single report in the literature about the existence or isolation of the separated dibrominated spirooxepinisoxazoline moiety (subunit A). The substituted and dibrominated spirooxepinisoxazoline unit has been always associated with the moloka'iamine moiety via an amidic linkage [2-13]. This can be explained by the necessity of such a combination as a defense tool for sponges against predators in the field.

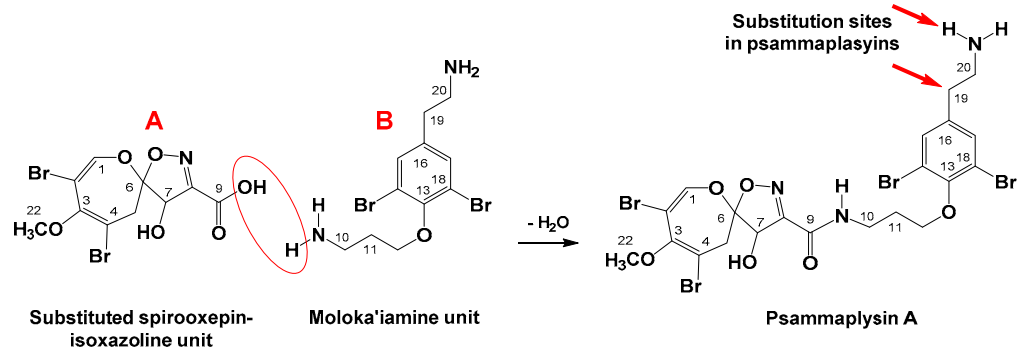

Figure 1. Subunits of the psammaplysins' backbone.

To date, 41 bromotyrosine derivatives with the spirooxepinisoxazoline skeleton have been isolated. These compounds include psammaplysins A-Y (25 compounds), 19-hydroxy derivatives of psammaplysins E, P, Q, S, T, U, W, and X (eight compounds), psammaplysin K-dimethyl acetal (one compound) [2-11], ceratinamides A and B and 19-hydroxyceratinamide A (three compounds) [9,10], ceratinadins E and F (two compounds) [12], and recently, frondoplysins A and B (two compounds) [13]. Psammaplysins were reported mainly from two orders including several representatives from the genera Aplysinella, Psammaplysinella, Pseudoceratina, and Suberea of the order Verongida [2-10,12] and only two representatives, Hyatella sp. [11] and Dysidea frondosa [13], from the order Dictyoceratida. The common substitution patterns on the psammaplysins' backbone exist only on the terminal ethylamine $\left(\mathrm{CH}_{2} \mathrm{CH}_{2} \mathrm{NH}_{2}\right)$ part of the moloka'iamine subunit. Hydyoxylation or acylation at C-19 and/or $N$-alkylation or acylation with different fatty acids' moieties represent the major substitution patterns on the psammaplysins' skeleton [2-11]. Exceptionally, ceratinadins E and F possess two or three moloka'iamine subunits attached to the spirooxepinisoxazoline unit through amidic linkages [12]. Interestingly, frondoplysins A and B from Dysidea frondosa [13] possess an unusual meroterpene unit attached to the terminal amine of the psammaplysins [13].

As a part of our ongoing work on the Red Sea Verongiid sponges [15], we investigated the cytotoxic extracts of the sponge Aplysinella species. Two new bromotyrosine-derived compounds, psammaplysin Z (1) and 19-hydroxypsammaplysin Z (2), together with the known psammaplysins A (3) [2] and E (4) [4], were isolated. The structural determination of 1-4 was established by assignment of their NMR and high-resolution electrospray ionization mass spectrometry (HRESIMS) data. Herein, the assignment of the structures as well as the cytotoxic activities of 1-4 was reported.

\section{Results and Discussion}

\subsection{Isolation of Compounds $\mathbf{1}-\mathbf{4}$}

Extraction of the sponge Aplysinella species with $\mathrm{MeOH}$ and successive partition of the aqueous $\mathrm{MeOH}$ extract against hexane, $\mathrm{CH}_{2} \mathrm{Cl}_{2}$, and EtOAc afforded three organic fractions. The cytotoxic $\mathrm{CH}_{2} \mathrm{Cl}_{2}$ fraction was acidified with dilute $\mathrm{HCl}$ and re-extracted with $\mathrm{CH}_{2} \mathrm{Cl}_{2}$. Repeated chromatographic fractionation of the organic extract, successive fractions on $\mathrm{SiO}_{2}$, Sephadex LH-20, and Sep-Pak C18 
cartridge columns, and purification of the cytotoxic subfractions on a reversed-phase C18 HPLC column afforded compounds 1-4 (Figure 2).

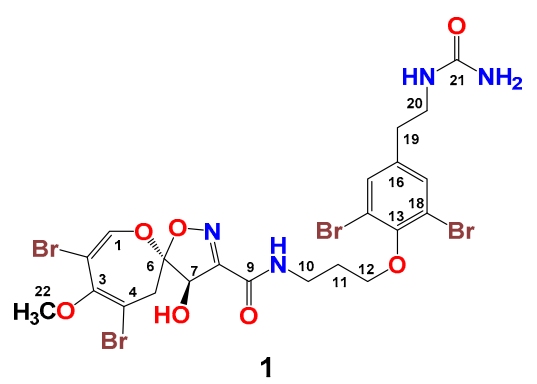<smiles>COC1C(Br)CC2(OOC2(O)C(O)C(=O)NCCCOc2c(Br)cc(C(O)NC(N)=O)cc2Br)OC1Br</smiles>

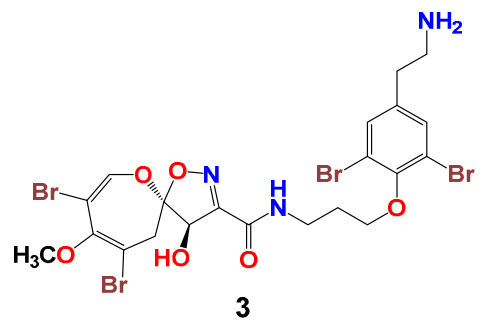

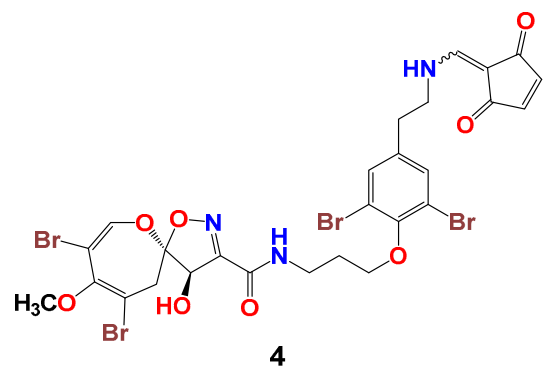

Figure 2. Chemical structures of psammaplysin Z (1), 19-hydroxypsammaplysin Z (2), psammaplysins A (3) and E (4).

\subsection{Structural Determination of Compounds $\mathbf{1}-\mathbf{4}$}

Psammaplysin Z (1) (Figure 2) was isolated as an optically active yellow solid with the molecular formula $\mathrm{C}_{22} \mathrm{H}_{24} \mathrm{Br}_{4} \mathrm{~N}_{4} \mathrm{O}_{7}$, requiring 11 degrees of unsaturation. The tetrabrominated nature of $\mathbf{1}$ was supported from the 1:4:6:4:1 ion cluster, which was displayed by the pseudomolecular ion peaks in the HRESIMS (Supplementary Figure S1) at $m / z$ values of 772.8, 774.8, 776.8, 778.8, and 780.8 $[\mathrm{M}+\mathrm{H}]^{+}$. Investigation of the NMR spectra of 1 including ${ }^{1} \mathrm{H}$ (Supplementary Figure S2), ${ }^{13} \mathrm{C}$ (Supplementary Figure S3), DEPT (Supplementary Figure S4), ${ }^{1} \mathrm{H}-{ }^{1} \mathrm{H}$ COSY (Supplementary Figure S5), and HSQC (Supplementary Figure S6) experiments supported the presence of four methine groups, six methylenes group, one methyl group, and 11 quaternary carbons. The signals at $\delta_{\mathrm{H} / \mathrm{C}}$ values of $7.16(1 \mathrm{H}, \mathrm{s}) / 146.9$ (CH, C-1), 104.5 (qC, C-2), 150.0 (qC, C-3), 104.6 (qC, C-4), $3.38(1 \mathrm{H}, \mathrm{d}$, $J=16.0 \mathrm{~Hz})$ and $3.08(1 \mathrm{H}, \mathrm{d}, J=16.0 \mathrm{~Hz}) / 38.4\left(\mathrm{CH}_{2}, \mathrm{C}-5\right), 121.0(\mathrm{qC}, \mathrm{C}-6), 5.00(1 \mathrm{H}, \mathrm{s}) / 80.5(\mathrm{CH}$, C-7), 159.0 (qC, C-8), 160.8 (qC, C-9), and $3.67(3 \mathrm{H}, \mathrm{s}) / 59.4\left(\mathrm{CH}_{3}, \mathrm{C}-22\right)$ are characteristic for the 2,3,4,7,9-penta-substituted spirooxepinisoxazoline unit [2-13]. The HMBC experiment (Supplementary Figure S7) supported and secured the placement of the substituents on the spirooxepinisoxazoline moiety as "2,4-dibromo-7-hydroxy-3-methoxy-9-carbonyl" (Figure 2). For example, the HMBC correlations from $\mathrm{H}-1$ to $\mathrm{C}-2, \mathrm{C}-3$, and $\mathrm{C}-6$, from $\mathrm{H}_{2}-5$ to $\mathrm{C}-3, \mathrm{C}-4$, and $\mathrm{C}-6$, from $\mathrm{H}-7$ to $\mathrm{C}-6, \mathrm{C}-8$, and C-9, and from $\mathrm{OCH}_{3}$ to $\mathrm{C}-3$ (Table 1 and Figure 3) supported the quaternary carbons' assignment, the placement of the substituents on the spirooxepinisoxazoline skeleton, and the assignment of the first subunit of $\mathbf{1}$. 
Table 1. NMR spectral data of psammaplysin Z (1) $\left(\mathrm{CD}_{3} \mathrm{OD}\right)$.

\begin{tabular}{|c|c|c|c|}
\hline Position & $\delta_{C}$ (mult.) $*$ & $\delta_{H}($ mult., $J(\mathrm{~Hz}))$ & НМВС \\
\hline 1 & $146.9, \mathrm{CH}$ & $7.16(1 \mathrm{H}, \mathrm{s})$ & $C-2, C-3, C-6$ \\
\hline 2 & 104.5, qC & & \\
\hline 3 & $150.0, \mathrm{qC}$ & & \\
\hline 4 & 104.6, qC & & \\
\hline $5 a$ & & $3.38(1 \mathrm{H}, \mathrm{d}, 16.0)$ & $C-3, C-4, C-6$ \\
\hline $5 b$ & $38.4, \mathrm{CH}_{2}$ & $3.08(1 \mathrm{H}, \mathrm{d}, 16.0)$ & $C-3, C-4, C-6$ \\
\hline 6 & 121.0, qC & & \\
\hline 7 & $80.5, \mathrm{CH}$ & $5.00(1 \mathrm{H}, \mathrm{s})$ & C-6, C-8, C-9 \\
\hline 8 & 159.0, qC & & \\
\hline 9 & $160.8, \mathrm{qC}$ & & \\
\hline 10 & $38.1, \mathrm{CH}_{2}$ & $3.64(2 \mathrm{H}, \mathrm{t}, 6.5)$ & C-9, C-11, C-12 \\
\hline 11 & $30.7, \mathrm{CH}_{2}$ & 2.15 (2H, quin., 6.5) & C-10, C-12 \\
\hline 12 & $72.2, \mathrm{CH}_{2}$ & $4.08(2 \mathrm{H}, \mathrm{t}, 6.5)$ & C-10, C-11, C-13 \\
\hline 13 & 153.0, qC & & \\
\hline 14 & $119.1, \mathrm{qC}$ & & \\
\hline 15 & $134.4, \mathrm{CH}$ & $7.49(1 \mathrm{H}, \mathrm{s})$ & C-13, C-14, C-18, C-19 \\
\hline 16 & $139.8, \mathrm{qC}$ & & \\
\hline 17 & $134.4, \mathrm{CH}$ & $7.49(1 \mathrm{H}, \mathrm{s})$ & C-13, C-14, C-18, C-19 \\
\hline 18 & $119.1, \mathrm{qC}$ & & \\
\hline 19 & $35.1, \mathrm{CH}_{2}$ & $2.78(2 \mathrm{H}, \mathrm{t}, 6.6)$ & C-16, C-17, C-20 \\
\hline 20 & $40.1, \mathrm{CH}_{2}$ & $3.46(2 \mathrm{H}, \mathrm{t}, 6.6)$ & C-16, C-19, C-21 \\
\hline 21 & $161.6, \mathrm{qC}$ & & \\
\hline 22 & $59.4, \mathrm{CH}_{3}$ & $3.67(3 \mathrm{H}, \mathrm{s})$ & $C-3$ \\
\hline
\end{tabular}

* Signal multiplicities were determined from DEPT and HSQC experiments.

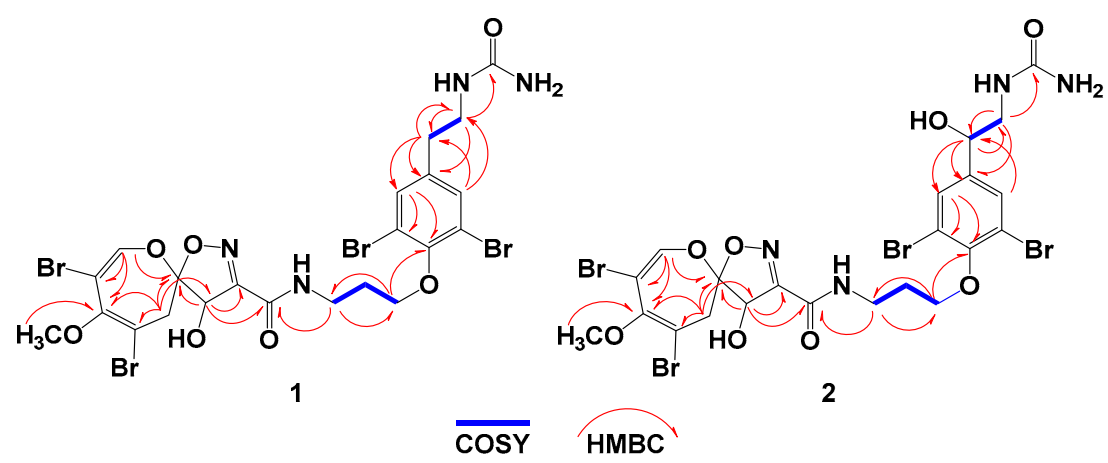

Figure 3. Observed COSY and ${ }^{2} J_{\mathrm{CH}}$ and ${ }^{3} J_{\mathrm{CH}} \mathrm{HMBC}$ correlations of $\mathbf{1}$ and $\mathbf{2}$.

The second substructure of $\mathbf{1}$ was assigned as the $N, N$-disubstituted moloka'iamine moiety, as supported by investigation of the ${ }^{1} \mathrm{H},{ }^{13} \mathrm{C}, \mathrm{COSY}$, and $\mathrm{HSQC}$ experiments. In the second substructure of 2, two spin-spin coupling systems with vicinal couplings $\left({ }^{3} J_{\mathrm{HH}}=6.5-6.6 \mathrm{~Hz}\right)$ were traced from $\mathrm{H}_{2}-10$ to $\mathrm{H}_{2}-12$ and between $\mathrm{H}_{2}-19$ and $\mathrm{H}_{2}-20$, respectively. The $\delta_{\mathrm{H} / \mathrm{C}}$ values of $3.64(2 \mathrm{H}, \mathrm{t}) / 38.1\left(\mathrm{CH}_{2}, \mathrm{C}-10\right)$, $2.15(2 \mathrm{H}$, quin. $) / 30.7\left(\mathrm{CH}_{2}, \mathrm{C}-11\right), 4.08(2 \mathrm{H}, \mathrm{t}) / 72.2\left(\mathrm{CH}_{2}, \mathrm{C}-12\right), 153.0(\mathrm{qC}, \mathrm{C}-13), 119.1(2 \times \mathrm{qC}, \mathrm{C}-14$, $\mathrm{C}-18), 7.49(2 \mathrm{H}, \mathrm{s}) / 134.4(2 \times \mathrm{CH}, \mathrm{C}-15, \mathrm{C}-17), 139.8(\mathrm{qC}, \mathrm{C}-16), 2.78(2 \mathrm{H}, \mathrm{t}) / 35.1\left(\mathrm{CH}_{2}, \mathrm{C}-19\right)$, and 3.46 $(2 \mathrm{H}, \mathrm{t}) / 40.1\left(\mathrm{CH}_{2}, \mathrm{C}-20\right)$ supported the presence of the $\mathrm{N}, \mathrm{N}$-disubstituted moloka'iamine moiety $[14,15]$. The HMBC correlations (Table 1 and Figure 3) from $\mathrm{H}_{2}-10$ to $\mathrm{C}-11$ and $\mathrm{C}-12$, from $\mathrm{H}_{2}-11$ to $\mathrm{C}-10$ and C-12, from $\mathrm{H}_{2}-12$ to $\mathrm{C}-10, \mathrm{C}-11$ and $\mathrm{C}-13\left(\delta_{\mathrm{C}}=153.0\right)$, from $\mathrm{H}-15 / 17$ to $\mathrm{C}-13, \mathrm{C}-14 / \mathrm{C}-18\left(\delta_{\mathrm{C}} 119.1\right)$, and $\mathrm{C}-19\left(\delta_{\mathrm{C}}=35.1\right)$, from $\mathrm{H}_{2}-19$ to $\mathrm{C}-16\left(\delta_{\mathrm{C}}=139.8\right), \mathrm{C}-17$, and $\mathrm{C}-20$, and finally from $\mathrm{H}_{2}-20$ to $\mathrm{C}-16$ and C-19 supported the assignment of the second subunit of compound $\mathbf{1}$.

The connection between the subunits of 1 via an amidic linkage (C-9) was supported by the HMBC correlations from H-7 $\left(\delta_{\mathrm{H}}=5.00\right)$ to $\mathrm{C}-9\left(\delta_{\mathrm{C}}=160.8\right)$ and from $\mathrm{H}_{2}-10\left(\delta_{\mathrm{H}}=3.64\right)$ to C-9 $\left(\delta_{C}=160.8\right)$ (Table 1 and Figure 3$)$. This connection supported the basic structure of 1 with elements of $\mathrm{C}_{21} \mathrm{H}_{22} \mathrm{Br}_{4} \mathrm{~N}_{3} \mathrm{O}_{6}$, which were counted for 10 degrees of unsaturation. The remaining elements of 
$\mathrm{CONH}_{2}$ were accounted for the last degree of unsaturation in $\mathbf{1}$ and were assigned as a terminal urea moiety. The attachment of the terminal urea moiety to the ethylamine of $\mathbf{1}$ was supported by the correlation in the HMBC experiment from $\mathrm{H}_{2}-20\left(\delta_{\mathrm{H}}=3.46\right)$ to $\mathrm{C}-21\left(\delta_{\mathrm{C}}=161.6\right)$ (Table 1 and Figure 3 ) to complete the planer structure of $\mathbf{1}$. Accordingly, compound $\mathbf{1}$ was assigned as psammaplysin $\mathrm{Z}$.

19-hydroxypsammaplysin $Z$ (2) (Figure 2) was isolated as an optically active solid. Its HRESIMS spectrum displayed the molecular formula of $\mathrm{C}_{22} \mathrm{H}_{24} \mathrm{Br}_{4} \mathrm{~N}_{4} \mathrm{O}_{8}$. The existence of four bromine atoms in 2 was established from the 1:4:6:4:1 pseudomolecular ion cluster in the HRESIMS (Supplementary Figure S8) at $m / z$ values of $788.8,790.8,792.8,794.8$, and $796.8[\mathrm{M}+\mathrm{H}]^{+}$. The molecular mass of 2 was 16 mass units lager than that of $\mathbf{1}$, which suggested an additional oxygen atom in $\mathbf{2}$. The extensive study and the assignment of the ${ }^{1} \mathrm{H}$ (Supplementary Figure S9) and ${ }^{13} \mathrm{C}$ NMR spectra (Supplementary Figure S10) and the DEPT (Supplementary Figure S11), ${ }^{1} \mathrm{H}-{ }^{1} \mathrm{H}$ COSY (Supplementary Figure S12), HSQC (Supplementary Figure S13), and HMBC experiments (Supplementary Figure S14) of 2 (Table 2) revealed similar NMR signals to those of psammaplysin Z (1) (Table 1).

Table 2. NMR spectral data of 19-hydroxypsammaplysin Z (2) $\left(\mathrm{CD}_{3} \mathrm{OD}\right)$.

\begin{tabular}{|c|c|c|c|}
\hline Position & $\delta_{C}$ (mult.) $*$ & $\delta_{H}($ mult., $J(\mathrm{~Hz}))$ & НМВС \\
\hline 1 & $146.8, \mathrm{CH}$ & $7.14(1 \mathrm{H}, \mathrm{s})$ & $C-2, C-3, C-6$ \\
\hline 2 & $104.2, \mathrm{qC}$ & & \\
\hline 3 & $149.8, \mathrm{qC}$ & & \\
\hline 4 & $104.5, \mathrm{qC}$ & & \\
\hline $5 a$ & \multirow{2}{*}{$38.2, \mathrm{CH}_{2}$} & $3.38(1 \mathrm{H}, \mathrm{d}, 16.0)$ & $C-3, C-4, C-6$ \\
\hline $5 b$ & & $3.05(1 \mathrm{H}, \mathrm{d}, 16.0)$ & $C-3, C-4, C-6$ \\
\hline 6 & $120.8, \mathrm{qC}$ & & \\
\hline 7 & $80.4, \mathrm{CH}$ & $4.97(1 \mathrm{H}, \mathrm{s})$ & $C-6, C-8, C-9$ \\
\hline 8 & $158.8, \mathrm{qC}$ & & \\
\hline 9 & $160.7, \mathrm{qC}$ & & \\
\hline 10 & $37.9, \mathrm{CH}_{2}$ & $3.61(2 \mathrm{H}, \mathrm{t}, 6.5)$ & C-9, C-11, C-12 \\
\hline 11 & $30.5, \mathrm{CH}_{2}$ & $2.12(2 \mathrm{H}$, quin., 6.5$)$ & C-10, C-12 \\
\hline 12 & $72.0, \mathrm{CH}_{2}$ & $4.06(2 \mathrm{H}, \mathrm{t}, 6.5)$ & C-10, C-11, C-13 \\
\hline 13 & $153.5, \mathrm{qC}$ & & \\
\hline 14 & $119.2, \mathrm{qC}$ & & \\
\hline 15 & 131.7, CH & $7.60(1 \mathrm{H}, \mathrm{s})$ & C-13, C-14, C-18, C-19 \\
\hline 16 & $143.2, \mathrm{qC}$ & & \\
\hline 17 & $131.7, \mathrm{CH}$ & $7.60(1 \mathrm{H}, \mathrm{s})$ & C-13, C-14, C-18, C-19 \\
\hline 18 & $119.2, \mathrm{qC}$ & & \\
\hline 19 & $71.5, \mathrm{CH}$ & $4.69(1 \mathrm{H}, \mathrm{dd}, 9.5,3.0)$ & C-15, C-16, C-17, C-20 \\
\hline $20 a$ & \multirow{2}{*}{$46.2, \mathrm{CH}_{2}$} & $3.47(1 \mathrm{H}, \mathrm{dd}, 13.0,3.0)$ & C-16, C-19, C-21 \\
\hline $20 \mathrm{~b}$ & & $3.31(1 \mathrm{H}, \mathrm{m})$ & C-16, C-19, C-21 \\
\hline 21 & $161.2, \mathrm{qC}$ & & \\
\hline 22 & $59.3, \mathrm{CH}_{3}$ & $3.63(3 \mathrm{H}, \mathrm{s})$ & $C-3$ \\
\hline
\end{tabular}

* Signal multiplicities were determined from DEPT and HSQC experiments.

The difference between the NMR spectra of compounds $\mathbf{1}$ and $\mathbf{2}$ was related to the signals of the ethylamine part of the moloka'iamine moiety (Figure 2 and Tables 1 and 2). The NMR signals of the ethylamine fragment $(\mathrm{C}-19$ and $\mathrm{C}-20)$ at $\delta_{\mathrm{H} / \mathrm{C}}$ values of $2.78(2 \mathrm{H}, \mathrm{t}) / 35.1\left(\mathrm{CH}_{2}, \mathrm{C}-19\right)$ and 3.46 $(2 \mathrm{H}, \mathrm{t}) / 40.1\left(\mathrm{CH}_{2}, \mathrm{C}-20\right)$ (Table 1$)$ were absent in 2 . Instead, new signals at $\delta_{\mathrm{H} / \mathrm{C}}$ values of $4.69(1 \mathrm{H}$, dd)/71.5 (CH, C-19), $3.47(1 \mathrm{H}, \mathrm{dd})$, and $3.31(1 \mathrm{H}, \mathrm{m}) / 46.2\left(\mathrm{CH}_{2}, \mathrm{C}-20\right)$ were observed in 2 (Table 2), suggesting the hydroxylation of C-19. This was supported from downfield-shifted signals of H-19/C-19 at the $\delta_{\mathrm{H} / \mathrm{C}}$ value of $4.69 / 71.5$ and the vicinal couplings between $\mathrm{H}-19\left(\delta_{\mathrm{H}}=4.69 ; \mathrm{J}=9.3\right.$ and $\left.3.0 \mathrm{~Hz}\right)$ and $\mathrm{H}-20 \mathrm{a}\left(\delta_{\mathrm{H}}=3.47\right)$ and $\mathrm{H}-20 \mathrm{~b}\left(\delta_{\mathrm{H}}=3.31\right)$ in the COSY experiment. Furthermore, the presence of the $\mathrm{C}-19 \mathrm{OH}$ group was supported again by HMBC experiments. The correlations from $\mathrm{H}-19\left(\delta_{\mathrm{H}}\right.$ $=4.69)$ to $\mathrm{C}-15 / \mathrm{C}-17\left(\delta_{\mathrm{C}}=131.7\right), \mathrm{C}-16\left(\delta_{\mathrm{C}}=143.2\right)$, and $\mathrm{C}-20\left(\delta_{\mathrm{C}}=46.2\right)$ and from $\mathrm{H}_{2}-20\left(\delta_{\mathrm{H}} 3.47\right.$ and 3.31) to C-16, C-15/C-17, C-19 $\left(\delta_{C}=71.5\right)$, and C-21 $\left(\delta_{C}=161.2\right)$ supported the hydroxylation 
of C-19 and completed the assignment of compound 2. Accordingly, compound $\mathbf{2}$ was identified as 19-hydroxypsammaplysin Z.

Compounds 3 and 4 (Figure 2) were identified as the previously reported psammaplysin A [2] and psammaplysin E [4], respectively, after extensive and careful investigations of their 1D and 2D NMR and MS spectra and by comparison of their data with the literature [2,4].

Compounds 1-4 displayed optical rotations with negative signs and similar magnitudes. Therefore, it was more likely that psammaplysins 1-4 possessed the same biosynthetic pathway and shared similar absolute configurations of the spirooxepinisoxazoline moiety. In addition, the signs and the magnitudes of the optical rotations of compounds 1-4 were closely related to the literature $[2,4,6,8,9,11]$. Recently, the absolute stereochemistry of C-6 and C-7 of psammaplysin A was verified as $6 R$ and $7 R$, respectively [16]. Therefore, we assume that compounds $\mathbf{1}-\mathbf{4}$ share the same absolute configurations of C-6 and C-7 with psammaplysin A [16]. However, the stereochemistry of C-19 of 19 substituted psammaplysins $[2,4,7,9-11]$ has not been established so far.

\subsection{Biological Activities of Compounds 1-4}

The reported pharmacological properties associated with the psammaplysins are diverse and include cytotoxicity, antimalarial, antiviral, antifouling, antimicrobial, and antioxidant activities. Psammaplysins A-C displayed cytotoxic activity against HCT 116 cell lines [3]. On the other hand, psammaplysin D possessed antiviral activity against HIV-1 virus at $0.1 \mu \mathrm{g} / \mathrm{mL}$ [4]. Psammaplysin E was cytotoxic to LoVo and $\mathrm{KB}$ cell lines at $5.0 \mu \mathrm{g} / \mathrm{mL}$ and showed moderate immunosuppressive activity [4]. It was also effective as a potent antimigratory agent against HeLa and MDA-MB-231 cells with $\mathrm{IC}_{50}$ values of 2.19 and $0.31 \mu \mathrm{M}$, respectively [15]. 19-hydroxypsammaplysin E displayed moderate antimalarial activity against 3D7 drug-sensitive strain of $P$. falciparum with an $\mathrm{IC}_{50}$ value of $6.4 \mu \mathrm{M}$ [8]. Furthermore, psammaplysin F inhibited $80 \%$ of four bacterial strains at $50 \mu \mathrm{M}$ [17] and showed antiplasmodial activity against 3D7 and Dd2 strains of $P$. falciparum with $\mathrm{IC}_{50}$ values of 0.87 and $1.4 \mu \mathrm{M}$, respectively [11]. When tested against the drug-resistant (K1) and drug-sensitive (FCR3) strains of $P$. falciparum, psammaplysin $\mathrm{F}$ was active with $\mathrm{IC}_{50}$ values of 3.77 and $2.45 \mu \mathrm{g} / \mathrm{mL}$ against these strains [12]. Recently, psammaplysin F was found to regulate the synthesis of stress granules, leading to increasing the efficacy of bortezomib and sorafenib [18]. Psammaplysin G showed $98 \%$ inhibition of the Dd2 cell strain of P. falciparum at $40 \mu \mathrm{M}$ [11]. Similarly, psammaplysin H possessed potent antiplasmodial activity against the $3 \mathrm{D} 7$ strain with an $\mathrm{IC}_{50}$ value of $0.41 \mu \mathrm{M}$ [6]. Psammaplysin $\mathrm{H}$ was also selective towards the 3D7 strain with a selectivity index (SI) of $>97 \%$ [6]. Psammaplysins X and Y and 19-hydroxypsammaplysin $X$ showed potent cytotoxicity towards six cancer cell lines with a $\mathrm{GI}_{50}$ value down to $0.8 \mu \mathrm{M}$ [9]. When evaluated for their antiplasmodial activities, ceratinadin $\mathrm{E}$ displayed higher activity against FCR3 $\left(\mathrm{IC}_{50}=0.77 \mu \mathrm{g} / \mathrm{mL}\right)$ and $\mathrm{K} 1\left(\mathrm{IC}_{50}=1.03 \mu \mathrm{g} / \mathrm{mL}\right)$ strains of P. falciparum than ceratinadin $\mathrm{F}$, which displayed weak activity with an $\mathrm{IC}_{50}$ value of $>12.5 \mu \mathrm{g} / \mathrm{mL}$ against the drug-resistant K1 strain [12]. Frondoplysin A potently inhibited the protein tyrosine phosphatase 1B with an $\mathrm{IC}_{50}$ value of $0.39 \mu \mathrm{M}$ and displayed antioxidant activity in transgenic zebrafish without any cytotoxicity [13]. Finally, ceratinamides A and B displayed antifouling activity through inhibition of metamorphosis and settlement of the barnacle B. amphitrite with an $\mathrm{ED}_{50}$ range of 0.1-8.0 $\mathrm{\mu g} / \mathrm{mL}$ [11].

In order to evaluate the cytotoxic activities of 1-4, the compounds were screened in an MTT assay $[19,20]$ against three human cancer cell lines, including the triple-negative breast cancer (MDA-MB-231, ATCC HTB-26), cervical carcinoma (HeLa, ATCC CCL-2), and colorectal carcinoma (HCT 116, ATCC CCL-247). Psammaplysin E (4) displayed the strongest activity againt MDA-MB-231 and HeLa cells with $\mathrm{IC}_{50}$ values of 0.29 and $2.1 \mu \mathrm{M}$, respectively, while psammaplysin A (3) was less active than 4 with $\mathrm{IC}_{50}$ values of 3.9 and $8.5 \mu \mathrm{M}$, respectively (Table 3). Moreover, both compounds were less active againt HCT 116 with $\mathrm{IC}_{50}$ values of 5.1 and $3.7 \mu \mathrm{M}$, respectively. On the other hand, compounds $\mathbf{1}$ and $\mathbf{2}$ were weakly active against MDA-MB-231 and HeLa cells with $\mathrm{IC}_{50}$ values ranging from 13.2 to $22.2 \mu \mathrm{M}$ (Table 3), but when tested againt HCT 116, they showed better sensitivity towards this cell line with $\mathrm{IC}_{50}$ values of 8.2 and $7.0 \mu \mathrm{M}$, respectively. 
Table 3. Cytotoxic activities of compounds 1-4.

\begin{tabular}{cccc}
\hline \multirow{2}{*}{ Compound } & \multicolumn{2}{c}{ IC $_{50}(\mu \mathrm{M})$} \\
\cline { 2 - 4 } & MDA-MB-231 & HeLa & HCT 116 \\
\hline 1 & $19.4 \pm 1.80$ & $22.2 \pm 2.0$ & $8.2 \pm 0.72$ \\
2 & $13.2 \pm 0.45$ & $17.6 \pm 1.90$ & $7.0 \pm 0.65$ \\
3 & $3.90 \pm 0.20$ & $8.50 \pm 0.81$ & $5.1 \pm 0.41$ \\
4 & $0.29 \pm 0.05$ & $2.10 \pm 0.12$ & $3.7 \pm 0.31$ \\
5-fluorouracil (5-FU) * & $13.0 \pm 0.30$ & $12.3 \pm 0.25$ & $4.6 \pm 0.23$ \\
\hline
\end{tabular}

* Positive cytotoxicity control. Data are presented as the mean $\pm \mathrm{SD} ; n=3$.

The above data suggested, in general, the importance of the spirooxepinisoxazoline moiety in compounds 1-4 for cytotoxic activities. Additionally, the potency of the activities of the psammapysins depended mainly on the type of the substituents on the terminal amino group of the psammaplysins. For example, the presence of the 2-(methylene)cyclopent-4-ene-1,3-dione moiety in 4 caused higher and better sensitivity towards MDA-MB-231 and HeLa cells over the terminal amine in 3, which was displayed by the potent cytotoxic activity of 4 against both cell lines down to $0.20 \mu \mathrm{M}$. Moreover, both $\mathbf{1}$ and $\mathbf{2}$ were weakly active against these cells as a result of the presence of the terminal urea moiety in both compounds. In addition, compounds 3 and 4 displayed better sensitity against HCT 116 than MDA-MB-231 and HeLa cell lines.

These results clearly indicated that both MDA-MB-231 and HeLa cells possess high sensitivity towards psammaplysins A (3) and E (4). Thus, psammaplysins A and E are considered as an attractive molecular scaffold for the development of anticancer drugs.

\section{Material and Methods}

\subsection{General Experimental Procedures}

The optical rotations of the compounds were acquired on a digital DIP-370 polarimeter (JASCO, Oklahoma City, OK, USA). The UV spectra were measured on a Hitachi 300 spectrometer (Hitachi High-Technologies Corporation, Kyoto, Japan). 1D and 2D NMR spectra were recorded on a Bruker Avance DRX $600 \mathrm{MHz}$ (Bruker, Rheinstetten, Germany) spectrometer using $\mathrm{CD}_{3} \mathrm{OD}$ as a solvent. NMR spectra were referenced to the residual protonated solvent signal $\left(\mathrm{CH}_{3} \mathrm{OH}: 3.30\right.$ for ${ }^{1} \mathrm{H}$ and $49.0 \mathrm{ppm}$ for ${ }^{13} \mathrm{C}$ ). Positive-ion HRESIMS data were obtained with a Micromass Q-ToF spectrometer (Waters Corporation, Milford, MA, USA).

\subsection{Biological Materials}

The sponge, Aplysinella species, was harvested from the Red Sea coast off Jizan, KSA, at a depth of $15 \mathrm{~m}$ using SCUBA (Self-Contained Underwater Breathing Apparatus) diving. The sponge formed an irregular, thick, fleshy, and compressible yellow sheet with a thickness up to $7 \mathrm{~cm}$ thick. The color in life was bright yellow and turned into greenish-black after exposure to air and to completely black after storage in a $70 \%$ EtOH solution. The sponge was identified at the Department of Marine Sciences at the Faculty of Science of Suez Canal University (Ismailia, Egypt). A voucher sample of the sponge was stored at the Department of Pharmacognosy of Suez Canal University (Ismailia, Egypt) under collection \#DY-78.

\subsection{Purification of Compounds $\mathbf{1}-\mathbf{4}$}

The sponge was lyophilized, and the dried materials ( $520 \mathrm{~g}$ ) were macerated in $\mathrm{MeOH}$ at room temperature for $24 \mathrm{~h}(3 \times 2000 \mathrm{~mL})$. The methanolic extracts were filtered and concentrated under vacuum to yield $7.3 \mathrm{~g}$. The dried extract was suspended in a $\mathrm{MeOH}-\mathrm{H}_{2} \mathrm{O}(6: 4, v / v)$ solution and successively partitioned against hexane, $\mathrm{CH}_{2} \mathrm{Cl}_{2}$, and EtOAc. The cytotoxic $\mathrm{CH}_{2} \mathrm{Cl}_{2}$ extract $(2.9 \mathrm{~g})$ was dissolved in $\mathrm{MeOH}$ and diluted with aqueous $\mathrm{HCl}\left(\mathrm{pH}\right.$ : 3-4) followed by extraction with $\mathrm{CH}_{2} \mathrm{Cl}_{2}$. 
The concentration of the $\mathrm{CH}_{2} \mathrm{Cl}_{2}$ extract gave a dark yellow residue $(1.20 \mathrm{~g})$. The residue was partitioned over a $\mathrm{SiO}_{2}$ (Merck, 70-230 mesh ASTM) Vacuum Liquid Chromatography (VLC) column using hexane/EtOAc/ $\mathrm{MeOH}$ with increasing polarity to give seven major fractions (A-G). Fractionation of the cytotoxic fraction (Fraction D) on a Sephadex LH 20 (0.25-0.1 mm, Pharmacia) column with $\mathrm{MeOH}$ gave four major subfractions (D1-D4). Fraction D2 (115 mg) was fractionated on a C-18 RP Sep-Pak cartridge ( $1.0 \mathrm{~g}$, $6 \mathrm{cc}$ vacuum cartridge, Waters) with a $\mathrm{H}_{2} \mathrm{O} / \mathrm{MeOH}$ mixture (the volume percentage of $\mathrm{MeOH}$ in the mixture increased from $20 \%$ to $100 \%$ gradually) to give five subfractions (D2A-D2E). The cytotoxic fraction D2C ( $35 \mathrm{mg})$ was purified on an ODS HPLC column $(250 \times 10 \mathrm{~mm}$, ARII, Cosmosil, Waters) using 75\% MeOH to yield compounds 3 ( $7.3 \mathrm{mg}$ ) and 4 (3.7 mg). Similarly, fraction D3 (98 mg) was purified on a C-18 RP Sep-Pak cartridge (1.0 g, 6 cc vacuum cartridge, Waters) with a $\mathrm{H}_{2} \mathrm{O} / \mathrm{MeOH}$ mixture (the volume percentage of $\mathrm{MeOH}$ in the mixture increased from $20 \%$ to $100 \%$ gradually) to give five subfractions (D3A-D3E). The cytotoxic fraction D3B (22 mg) was purified on an ODS HPLC column ( $250 \times 10 \mathrm{~mm}$, ARII, Cosmosil, Waters) using $80 \% \mathrm{MeOH}$ to afford compounds 1 ( $2.3 \mathrm{mg}), 2$ (2.7 mg), and 4 (1.8 mg).

\subsection{Spectral Data of the Compounds}

Psammaplysin Z (1): pale yellow solid; $[\alpha]_{\mathrm{D}}: 54^{\circ}$ (c 0.1, MeOH); UV (MeOH) $\lambda_{\max }(\log \varepsilon): 304$ (4.15) and 210 (4.85) nm; NMR data: Table 1; HRESIMS m/z: 772.8464 (calcd for $\mathrm{C}_{22} \mathrm{H}_{25} \mathrm{Br}_{4} \mathrm{~N}_{4} \mathrm{O}_{7}$, $\left.[\mathrm{M}+\mathrm{H}]^{+}, 772.8457\right)$.

19-hydroxypsammaplysin $\mathrm{Z}$ (2): yellow solid; $[\alpha]_{\mathrm{D}}: 61^{\circ}$ (c $\left.0.1, \mathrm{MeOH}\right) ; \mathrm{UV}(\mathrm{MeOH}) \lambda_{\max }(\log \varepsilon)$ : 305 (4.10) and 209 (4.90) nm; NMR data: Table 2; HRESIMS m/z: 788.8415 (calcd for $\mathrm{C}_{22} \mathrm{H}_{25} \mathrm{Br}_{4} \mathrm{~N}_{4} \mathrm{O}_{8}$, $\left.[\mathrm{M}+\mathrm{H}]^{+}, 788.8406\right)$.

\subsection{Cytotoxicity Evaluation of Compounds $\mathbf{1}-\mathbf{4}$}

\subsubsection{Preparations of Cell Lines and Cell Culture}

The cell lines used in this study were triple-negative breast cancer (MDA-MB-231 (ATCC HTB-26)), human cervical carcinoma (HeLa (ATCC CCL-2)), and colorectal carcinoma (HCT 116 (ATCC CCL-247)). The MDA-MB-231 cells were cultured in DMEM containing 10\% FBS and 1\% penicillin-streptomycin, while HeLa and HCT 116 cells were cultured in RPMI 1640 containing 10\% FBS and $1 \%$ penicillin-streptomycin. All cells were cultured in an incubator at $37^{\circ} \mathrm{C}$ with $95 \%$ humidity and $5 \% \mathrm{CO}_{2}$.

\subsubsection{MTT Assay}

The evaluation of the cytotoxicity of the compounds was carried out using an MTT assay as previously described $[19,20]$. In brief, the cells were incubated at $37{ }^{\circ} \mathrm{C}$ overnight in $5 \% \mathrm{CO}_{2}$ /air. Compounds 1-4 were added to the top row of a 96-well microtiter plate and downward diluted serially $(1: 4, v / v)$. The cells were incubated with the compounds for $72 \mathrm{~h}$. Afterwards, viability of the cells was estimated at $490 \mathrm{~nm}$ using the Cell Titer 96 AQueous non-radioactive cell proliferation protocol (Promega, Madison, WI, USA) on a Molecular Devices Emax microplate reader. The $\mathrm{IC}_{50}$ values of the compounds (expressed in $\mu \mathrm{M}$ ) were evaluated using the program SOFTmax PRO (Molecular Devices, Sunnyvale, CA, USA). DMSO and 5-fluorouracil (5-FU) were used as negative and positive controls, respectively. The $\mathrm{IC}_{50}$ values represent the average of three independent experiments. The data are presented in Table 3.

\section{Conclusions}

In conclusion, the fractionation of the cytotoxic fractions of the methanolic extract of the Red Sea sponge Aplysinella species gave two new psammaplysins' derivatives, psammplysin Z (1) and 19-hydroxypsammaplyzin Z (2) together with the previously reported psammaplysins A (3) and E (4). Structures of the compounds were established by extensive interpretation of their NMR and MS 
spectroscopic data. In the cytotoxicity evaluation of the compounds, psammaplysin E (4) displayed the most potent activities against MDA-MB-231 and HeLa cells, while psammaplysin A (3), which contains a terminal amine, was less active than psammaplysin E. The results suggested the necessity of the rare 2-(methylene)cyclopent-4-ene-1,3-dione moiety in psammaplysin E for potent cytotoxic activity. On the other hand, psammpalysin Z (1) and 19-hydroxypsammaplysin Z (2) were moderately cytotoxic against both cell lines, which suggested again the preference of the free amino group in psammaplysin A (3) over the terminal urea moiety in $\mathbf{1}$ and $\mathbf{2}$ for the anticancer activity. Psammaplysins A and E showed potent cytotoxic activities against MDA-MB-231 and HeLa cells. Therefore, psammaplysins A and E, with the terminal amino group and 2-(methylene)cyclopent-4-ene-1,3-dione moiety, are considered as potential leads that can be developed as anticancer agents.

Supplementary Materials: Supplementary Materials are available at http://www.mdpi.com/2218-273X/9/12/841/s1. Figure S1: HRESIMS of psammaplysin Z (1), Figure S2: ${ }^{1} \mathrm{H}$ NMR spectrum of psammaplysin Z (1) $\left(\mathrm{CD}_{3} \mathrm{OD}\right)$, Figure S3: ${ }^{13} \mathrm{C}$ NMR spectrum of psammaplysin $\mathrm{Z}(\mathbf{1})\left(\mathrm{CD}_{3} \mathrm{OD}\right)$, Figure S4: DEPT spectrum of psammaplysin $\mathrm{Z}$ (1) $\left(\mathrm{CD}_{3} \mathrm{OD}\right)$, Figure $\mathrm{S} 5:{ }^{1} \mathrm{H}-{ }^{1} \mathrm{H}$ COSY spectrum of psammaplysin $\mathrm{Z}(\mathbf{1})\left(\mathrm{CD}_{3} \mathrm{OD}\right)$, Figure S6: HSQC spectrum of psammaplysin Z (1) $\left(\mathrm{CD}_{3} \mathrm{OD}\right)$, Figure S7: HMBC spectrum of psammaplysin Z (1) $\left(\mathrm{CD}_{3} \mathrm{OD}\right)$, Figure S8: HRESIMS of 19-hydroxypsammaplysin Z (2), Figure S9: ${ }^{1} \mathrm{H}$ NMR spectrum of 19 -hydroxypsammaplysin Z (2) (CD $\mathrm{CD}_{3} \mathrm{OD}$, Figure S10: ${ }^{13} \mathrm{C}$ NMR spectrum of 19-hydroxypsammaplysin Z (2) (CD $\left.\mathrm{CD}_{3} \mathrm{OD}\right)$, Figure S11: DEPT spectrum of psammaplysin $\mathrm{Z}(2)\left(\mathrm{CD}_{3} \mathrm{OD}\right)$, Figure S12: ${ }^{1} \mathrm{H}-{ }^{1} \mathrm{H}$ COSY spectrum of 19-hydroxypsammaplysin $\mathrm{Z}(2)\left(\mathrm{CD}_{3} \mathrm{OD}\right)$, Figure S13: HSQC spectrum of 19-hydroxypsammaplysin Z (2) (CD $\left.\mathrm{CD}_{3} \mathrm{OD}\right)$, Figure S14: HMBC spectrum of 19-hydroxypsammaplysin Z (2) (CD 3 OD).

Author Contributions: L.A.S. conceived and designed the experiments; L.A.S. and D.T.A.Y. performed the experiments; L.A.S. and D.T.A.Y. interpreted and analyzed the NMR and MS data; L.A.S. and D.T.A.Y. wrote the paper; D.T.A.Y. edited and revised the paper.

Funding: This project has received funding from the Deanship of Scientific Research (DSR), King Abdulaziz University, Jeddah, under grant No. G-1436-141-251.

Acknowledgments: This project was funded by the DSR, King Abdulaziz University, Jeddah, under grant No. G-1436-141-251. The authors, therefore, acknowledge with thanks DSR technical and financial support.

Conflicts of Interest: The authors declare no conflicts of interest.

\section{References}

1. Peng, J.; Li, J.; Hamann, M.T. The marine bromotyrosine derivatives. In The Alkaloids: Chemistry and Biology; Knölker, H.-J., Ed.; Academic Press: San Diego, CA, USA, 2005; Volume 61, pp. 59-262.

2. Roll, D.M.; Chang, C.W.J.; Scheuer, P.J.; Gray, G.A.; Shoolery, J.N.; Matsumoto, G.K.; Van Duyne, G.D.; Clardy, J. Structure of the psammaplysins. J. Am. Chem. Soc. 1985, 107, 2916-2920. [CrossRef]

3. Copp, B.R.; Ireland, C.M.; Barrows, L.R. Psammaplysin C: A new cytotoxic dibromotyrosine-derived metabolite from the marine sponge Druinella (= Psammaplysilla) purpurea. J. Nat. Prod. 1992, 55, 822-823. [CrossRef] [PubMed]

4. Ichiba, T.; Scheuer, P.J.; Kelly-Borges, M. Three bromotyrosine derivatives, one terminating in an unprecedented diketocyclopentenylidene enamine. J. Org. Chem. 1993, 58, 4149-4150. [CrossRef]

5. Liu, S.; Fu, X.; Schmitz, F.J.; Kelly-Borges, M. Psammaplysin F, a new bromotyrosine derivative from a sponge, Aplysinella sp. J. Nat. Prod. 1997, 60, 614-615. [CrossRef] [PubMed]

6. Xu, M.; Andrews, K.T.; Birrell, G.W.; Tran, T.L.; Camp, D.; Davis, R.A.; Quinn, R.J. Psammaplysin H, a new antimalarial bromotyrosine alkaloid from a marine sponge of the genus Pseudoceratina. Bioorg. Med. Chem. Lett. 2011, 21, 846-848. [CrossRef] [PubMed]

7. Wright, A.D.; Schupp, P.J.; Schrör, J.-P.; Engemann, A.; Rohde, S.; Kelman, D.; Voogd, N.D.; Carroll, A.; Motti, C.A. Twilight zone sponges from Guam yield theonellin isocyanate and psammaplysins I and J. J. Nat. Prod. 2012, 75, 502-506. [CrossRef] [PubMed]

8. Mudianta, I.W.; Skinner-Adams, T.; Andrews, K.T.; Davis, R.A.; Hadi, T.A.; Hayes, P.Y.; Garson, M.J. Psammaplysin derivatives from the Balinese marine sponge Aplysinella strongylata. J. Nat. Prod. 2012, 75, 2132-2143. [CrossRef] [PubMed] 
9. Lee, Y.J.; Han, S.; Lee, H.S.; Kang, J.S.; Yun, J.; Sim, C.J.; Shin, H.J.; Lee, J.S. Cytotoxic psammaplysin analogues from a Suberea sp. marine sponge and the role of the spirooxepinisoxazoline in their activity. J. Nat. Prod. 2013, 76, 1731-1736. [CrossRef] [PubMed]

10. Tsukamoto, S.; Kato, H.; Hirota, H.; Fusetani, N. Ceratinamides A and B: New antifouling dibromotyrosine derivatives from the marine sponge Pseudoceratina Purpurea. Tetrahedron 1996, 52, 8181-8186. [CrossRef]

11. Yang, X.; Davis, R.A.; Buchanan, M.S.; Duffy, S.; Avery, V.M.; Camp, D.; Quinn, R.J. Antimalarial bromotyrosine derivatives from the Australian marine sponge Hyattella sp. J. Nat. Prod. 2010, 73, 985-987. [CrossRef] [PubMed]

12. Kurimoto, S.I.; Ohno, T.; Hokari, R.; Ishiyama, A.; Iwatsuki, M.; Ōmura, S.; Kobayashi, J.; Kubota, T. Ceratinadins $\mathrm{E}$ and $\mathrm{F}$, new bromotyrosine alkaloids from an Okinawan marine sponge Pseudoceratina sp. Mar. Drugs. 2018, 16, 463. [CrossRef] [PubMed]

13. Jiao, W.H.; Li, J.; Zhang, M.M.; Cui, J.; Gui, Y.H.; Zhang, Y.; Li, J.Y.; Liu, K.C.; Lin, H.W. Frondoplysins A and B, unprecedented terpene-alkaloid bioconjugates from Dysidea frondosa. Org. Lett. 2019, 21, 6190-6193. [CrossRef] [PubMed]

14. Hamann, M.T.; Scheuer, P.J.; Kelly-Borges, M. Biogenetically diverse, bioactive constituents of a sponge, order Verongida: Bromotyramines and sesquiterpene-shikimate derived metabolites. J. Org. Chem. 1993, 58, 6565-6569. [CrossRef]

15. Shaala, L.A.; Youssef, D.T.A.; Badr, J.M.; Sulaiman, M.; Khedr, A.; El Sayed, K.A. Bioactive alkaloids from the Red Sea marine Verongid sponge Pseudoceratina arabica. Tetrahedron 2015, 71, 7837-7841. [CrossRef]

16. Mándi, A.; Mudianta, I.W.; Kurtán, T.; Garson, M.J. Absolute configuration and conformational study of psammaplysins A and B from the Balinese marine sponge Aplysinella strongylata. J. Nat. Prod. 2015, 78, 2051-2056. [CrossRef] [PubMed]

17. Ramsey, D.M.; Amirul, I.M.; Turnbull, L.; Davis, R.A.; Whitchurch, C.B.; McAlpine, S.R. Psammaplysin F: A unique inhibitor of bacterial chromosomal partitioning. Bioorg. Med. Chem. Lett. 2013, 23, 4862-4866. [CrossRef] [PubMed]

18. Christen, K.E.; Davis, R.A.; Kennedy, D. Psammaplysin F increases the efficacy of bortezomib and sorafenib through regulation of stress granule formation. Int. J. Biochem. Cell. Biol. 2019, 112, 24-38. [CrossRef] [PubMed]

19. Youssef, D.T.A.; Mooberry, S.L. Hurghadolide A and swinholide I, potent actin-microfilament disrupters from the Red Sea sponge Theonella swinhoei. J. Nat. Prod. 2006, 69, 154-157. [CrossRef] [PubMed]

20. Youssef, D.T.A.; Shaala, L.A.; Mohamed, G.A.; Badr, J.M.; Bamanie, F.H.; Ibrahim, S.R. Theonellamide G, a potent antifungal and cytotoxic bicyclic glycopeptide from the Red Sea marine sponge Theonella swinhoei. Mar. Drugs. 2014, 12, 1911-1923. [CrossRef] [PubMed] 